\title{
Sociodemographic Factors Related to the Incidence of Depression in the Elderly
}

\author{
Sandra Dewi ${ }^{1 *}$, Hidayati ${ }^{2}$, and Debby Silvia Dewi ${ }^{3}$ \\ ${ }^{1,2,3}$ Universitas Negeri Padang, Padang, Indonesia \\ *Corresponding author. Email: sd193576@gmail.com
}

\begin{abstract}
The World Healt Organization (WHO 2018) says nearly 400 million of the world's population suffer from mental disorders. Often it is not properly diagnosed, so it does not get proper treatment and treatment. In Indonesia with a variety of biological, psychological and social factors with diversity of the population, the number of cases of mental disorders continues to grow which has the effect of increasing the burden of the country and decreased human productivity for the long term. Mental health conditions are still one of the issues ruled out. In fact, the number of people with mental disorders continues to increase. Basic Health Research Data (Riskesda) 2018 , shows the prevalence of emotional mental disorders with symptoms of depression and anxiety. The government itself has listed treated mental disorders as one of 12 indicators of a family health approach. The purpose of the study was to determine sociodemographic factors associated with the incidence of depression in the elderly. This type of research is descriptive of analytics with a cross sectional study approach with a total of 59 respondents. (Notoatmodjo, 2010) using univariate analyzed instruments to obtain frequency distribution and bivariate with shi-square. The results were obtained data of respondents aged $60-65$ years $62.7 \%$, Gender $61 \%$ Male, Primary school education $69.5 \%$, working $57.6 \%$, marital status $78 \%$ married and non-depressed $81.4 \%$. There is a meaningful relationship between age, gender, occupation and marital status with the incidence of depression in the elderly and No relationship between the level of education and the incidence of depression. It is expected that respondents receive well to fill the busy and involve taking care of the household and participating in activities outside the house such as joining groups of mosques, elderly gymnastics and posyandu.
\end{abstract}

Keywords: Sociodemographic, Elderly and Depression

\section{INTRODUCTION}

Basic Health Research Data ( Riskesda ) 2018 , shows the prevalence of emosinal mental disorders with symptoms of depression and anxiety at the age of 15 reaches 14 million people. This is equivalent to $6 \%$ of Indonesia's population. Meanwhile, the prevalence of severe mental disorders such as schizophrenia reaches 400 thousand. The high number of people with mental disorders also goes hand in hand with our nation's life expectancy has increased significantly as well as a number of suicide cases in Indonesia.

But on the other hand, this rising life expectancy carries a burden on society. The increasing elderly population is not only a phenomenon in Indonesia, but also globally (Wahjudi Nugrobo,2012).

The elderly are seen as a group of people at risk of health problems, including mental health problems, including depressive disorders (Ministry of Health of the Republic of Indonesia [Ministry of Health], 2004). So far, the prevalence of depression in the world's elderly ranges from $8 \%-15 \%$ and the meta- analysis results from reports of countries around the world getting an average prevalence of depression in the elderly are $13.5 \%$ with a 14.1:8.6 female comparison. The prevalence of depression in the elderly undergoing treatment in hospitals and nursing homes amounted to 30-45 percent (Kompas, 2008).

Depression is the mental disorder that causes the most burden of disability, increasing morbidity, mortality, and risk of suicide. Depression is also associated with a person's sociodemographic factors. This is explained in the Canadian Community Health Survey which states that there are differences in depression rates between women and men, age, marital status, education level and type of work. (Canadian Medical Association Journal, 2000)

Depression is an afek disorder that often occurs in the elderly and is one of the emotional disorders. Symptoms of depression in the elderly can look like the elderly are less excited in living their lives, easily discouraged, activity decreased, lack of appetite, quick 
tiredness and difficulty sleeping at night (Nugroho, 1999). Elderly people with depression will have difficulty in meeting the needs of their daily activities (Palestine, 2006).

The results of interviews of 12 elderly people on May 19, 2019 who visited Public Health Center Sei Sarik Sub-District VII Padang Pariamann District showed that 7 elderly people of the female gender had some of the symptoms of depression where they revealed about the condition. In addition, 7 elderly people who are not working turn out to have more symptoms of depression because they are no longer able to earn their own income so have to rely on their lives in order to meet the daily needs of their children and grandchildren.

Meanwhile, eight more people aged 60-74 are men who work as retired civil servants and live only with elderly couples as well while their children rarely visit them. They think it is no longer needed, useless, unappreciated in their family and feel a burden on their family so rarely involved in solving problems in the family.

There is a problem, so researchers are interested in examining sociodemographic factors related to the incidence of depression in the elderly in the Working Area of Public Health Center Sei Sarik Sub-District VII Koto Padang Pariaman Regency.

\section{Formulation of the problem}

Based on the background of the problems mentioned above, the formulation of the problem that will be examined is: sociodemographic factors related to the incidence of depression in the elderly in the Working Area of Public Health Center Sei SarikKecamatan VII Koto Padang Pariaman Regency

\section{Objective of the research}

To find out the sociodemographic factors related to the incidence of depression in the elderly in the Working Area of Public Health Center Sei Sarik Kecamatan VII Koto Padang Pariaman Regency.

\section{Review of literature}

Late adulthood or old age, usually refers to the stage of the life cycle that begins at the age of 65 years. Gerontologists divide the elderly into two groups: young-olds, aged 65-74; and oldold, aged 75 and over. Sometimes used the term oldest old to refer to people aged 85 and over (Sadock \& Sadock, 2007).

Depression is a mood disorder. Mood is an c atmosphere of pervasive and sedentary feelings e. experienced internally and that affects a person's $f$. behavior and his perception of the world (Sadock \& g. Sadock, 2007). Poor social support and poor religious $h$. activity linked to depression in the elderly.

\section{METHOD OF RESEARCH}

This type of research is descriptive of analytics with a cross sectional study approach. The population in this study is all elderly people who are in the Working Area of Public Health Center Sei Sarik District VII Koto Padang Pariaman Regency as many as 590 people. A research sample of 59 people. Research time in July September 2019.

\section{RESULTS OF RESEARCH AND DISCUSSION}

\section{Result of research}

\section{Univariat Analysis}

Results of univariate analysis to see an overview of each variable in detail as follows:

Age

Table 1. Frequency Distribution of Respondents Based on Age in Korong Lohong Working Area of Public Health Center Sei sarik Padang Pariaman Regency

\begin{tabular}{|c|c|c|}
\hline Age & Frequency & \% \\
\hline $60-65$ & 37 & 62,7 \\
\hline $66-70$ & 13 & 22,0 \\
\hline $71-75$ & 2 & 3,4 \\
\hline$\geq 76$ & 7 & 11,9 \\
\hline Amount & $\mathbf{5 9}$ & $\mathbf{1 0 0}$ \\
\hline
\end{tabular}

Based on the table above can be seen that almost half of respondents, namely 37 people $(62.7 \%)$ 60-65 years old.

b. Gender

Table 2. Frequency Distribution of Respondents by Gender in Korong Lohong Working Area of Public Health Center Sei Sarik Padang Pariaman Regency

\begin{tabular}{|c|c|c|}
\hline Gender & Frequency & \% \\
\hline Female & 23 & 39 \\
\hline Male & 36 & 61 \\
\hline Amount & $\mathbf{5 9}$ & $\mathbf{1 0 0}$ \\
\hline
\end{tabular}

Based on the table above can be seen that almost half of respondents, namely 36 people $(61 \%)$ male. 
Profession

Table 3. Frequency Distribution of Respondents by Type of Work in Korong Lohong Working Area of Public Health Center Sei Sarik Padang Pariaman Regency

\begin{tabular}{|c|c|c|}
\hline Proffesion & Frequency & \% \\
\hline Working & 34 & 57,6 \\
\hline Jobless & 25 & 42,4 \\
\hline Amount & $\mathbf{5 9}$ & $\mathbf{1 0 0}$ \\
\hline
\end{tabular}

Based on the table above can be seen that more than half of respondents, namely 34 people $(57.6 \%)$ Work

Education

Table 4. Frequency Distribution of Respondents Based on Education in Korong Lohong Working Area of Public Health Center Sei Sarik Padang Pariaman Regency

\begin{tabular}{|c|c|c|}
\hline Education & Frequency & \% \\
\hline Elementary school & 41 & 69,5 \\
\hline Junior high school & 11 & 18,6 \\
\hline Senior high school & 6 & 10,2 \\
\hline College & 1 & 1,7 \\
\hline Amount & $\mathbf{5 9}$ & $\mathbf{1 0 0}$ \\
\hline
\end{tabular}

Based on the table above can be seen that 2 more than half of respondents, namely 41 people $(69.5 \%)$ elementary school-educated.

Marital Status

Table 5. Frequency Distribution of Respondents Based on Marital Status in Korong Lohong Working Area of
Public Health Center Sei Sarik Padang Pariaman Regency

\begin{tabular}{|c|c|c|}
\hline Marital status & Frequency & \% \\
\hline Married & 46 & 78 \\
\hline Not married & 13 & 22 \\
\hline Amount & $\mathbf{5 9}$ & $\mathbf{1 0 0}$ \\
\hline
\end{tabular}

Based on the table above can be seen that more than half of respondents, namely 46 people (78\%) married.

Incidence of Depression

Table 6. Frequency Distribution of Respondents Based on Depression Events in Korong Lohong Working Area of Public Health Center Sei Sarik Padang Pariaman Regency

\begin{tabular}{|c|c|c|}
\hline $\begin{array}{c}\text { Incidence of } \\
\text { depression }\end{array}$ & Frequency & $\mathbf{\%}$ \\
\hline Depression & 11 & 18,6 \\
\hline Not depression & 48 & 81,4 \\
\hline Amount & $\mathbf{5 9}$ & $\mathbf{1 0 0}$ \\
\hline
\end{tabular}

Based on the table above can be seen that the majority of respondents, namely 48 people $(81.4 \%)$ depression in the elderly.

\section{. Bivariate analysis}

Bivariate analysis is performed to see if the relationship between variables, as follows :

a. The Relationship of The Respondent's Age to the Incidence of Depression

Table 7. The Age Relationship of Respondents to The Incidence of Depression in The Working Area of Public Health Center Sei Sarik Padang Pariaman Regency

\begin{tabular}{|c|c|c|c|c|c|c|c|}
\hline \multirow{3}{*}{ Age } & \multicolumn{4}{|c|}{ Incidence of depression } & \multirow{2}{*}{\multicolumn{2}{|c|}{ Total }} & \multirow{3}{*}{ P Value } \\
\hline & \multicolumn{2}{|c|}{ Depression } & \multicolumn{2}{|c|}{$\begin{array}{c}\text { Not } \\
\text { depression }\end{array}$} & & & \\
\hline & $\mathbf{F}$ & $\%$ & $\mathbf{F}$ & $\%$ & $\mathbf{N}$ & $\%$ & \\
\hline $60-65$ & 5 & 13,5 & 32 & 86,5 & 37 & 100 & \\
\hline $66-70$ & 2 & 15,4 & 11 & 84,6 & 13 & 100 & \\
\hline $71-75$ & - & - & 2 & 10 & 2 & 100 & 0.045 \\
\hline$\geq 76$ & 4 & 57.1 & 3 & 42,9 & 7 & 100 & \\
\hline Amount & 11 & 18,6 & 48 & 64,7 & 59 & 100 & \\
\hline
\end{tabular}

Based on the table above it can be known that the percentage who experienced a higher incidence of depression was found in respondents who were the same age or over 76 years old with respondents aged $60-65$ years which is $57.1 \%: 13.3 \%$.
Chi Square's analysis yielded $\mathrm{p}=0.045<\alpha 0.05$. Ha's decision was accepted which meant there was a meaningful link between age and the incidence of depression in the elderly. 
Respondent's Gender Relationship with Depressive Events

Table 8. The Sex Relationship of Respondents with The Incidence of Depression in the Working Area of Public Health Center Sei Sarik Padang Pariaman Regency

\begin{tabular}{|c|c|c|c|c|c|c|c|}
\hline \multirow{3}{*}{ Gender } & \multicolumn{4}{|c|}{ Incidence of depression } & \multirow{2}{*}{\multicolumn{2}{|c|}{ Total }} & \multirow{3}{*}{ P Value } \\
\hline & \multicolumn{2}{|c|}{ Depression } & \multicolumn{2}{|c|}{$\begin{array}{c}\text { Not } \\
\text { Depression }\end{array}$} & & & \\
\hline & $\mathbf{F}$ & $\%$ & $\mathbf{F}$ & $\%$ & $\mathbf{N}$ & $\%$ & \\
\hline Female & 5 & 21,7 & 18 & 78,3 & 23 & 100 & \\
\hline Male & 6 & 16,7 & 30 & 83,3 & 36 & 100 & 0.037 \\
\hline Amount & 11 & 18,6 & 48 & 81,4 & 59 & 100 & \\
\hline
\end{tabular}

Based on the table above it can be known that the percentage who experienced a higher incidence of depression was found in respondents who were female with male respondents which was $21.7 \%: 16.7 \%$.

Chi Square's analysis yielded $\mathrm{p}=0.037<\alpha 0.05$.
Ha's decision was accepted which meant there was a meaningful link between the sexes and the incidence of depression in the elderly.

Respondent's Employment Relationship with Depressive Events

Table 9. The Relationship of The Respondent's Employment with The Incidence of Depression in the Working Area of Public Health Center Sei sarik Padang Pariaman Regency

\begin{tabular}{|c|c|c|c|c|c|c|c|}
\hline \multirow{2}{*}{ Employment } & \multicolumn{4}{|c|}{ Incidence of depression } & \multicolumn{2}{|c|}{\multirow{2}{*}{ Total }} & \multirow{2}{*}{ P Value } \\
\cline { 2 - 8 } & \multicolumn{2}{|c|}{ Depression } & \multicolumn{2}{|c|}{$\begin{array}{c}\text { Not } \\
\text { Depression }\end{array}$} & \multicolumn{2}{|c|}{} \\
\cline { 2 - 8 } & $\mathbf{F}$ & $\mathbf{\%}$ & $\mathbf{F}$ & $\mathbf{\%}$ & $\mathbf{N}$ & $\%$ & \\
\hline Jobless & 10 & 29,4 & 24 & 30,6 & 34 & 100 & \multirow{2}{*}{0,017} \\
\hline Working & 1 & 4,0 & 24 & 96 & 25 & 100 & \\
\hline Amount & $\mathbf{1 1}$ & $\mathbf{1 8 , 6}$ & $\mathbf{4 8}$ & $\mathbf{8 1 , 4}$ & $\mathbf{5 9}$ & $\mathbf{1 0 0}$ & \\
\hline
\end{tabular}

Based on the table above it can be known that the percentage who experienced a higher incidence of depression was found in respondents who did not work with working respondents which was $29.4 \%: 4.00 \%$.

Chi Square's analysis yielded a yield of $\mathrm{p}=$ $0.017<\alpha 0.05$. Ha's decision was accepted which meant there was a meaningful link between work and the incidence of depression in the elderly. The Respondent's Educational Relationship with The Incidence of Depression

Table 10. The Relationship of Education of Respondents to the Incidence of Depression in the Working Area of Public Health Center Sei Sarik Padang Pariaman Regency

\begin{tabular}{|c|c|c|c|c|c|c|c|}
\hline \multirow{3}{*}{ Education } & \multicolumn{4}{|c|}{ Incidence of depression } & \multirow{2}{*}{\multicolumn{2}{|c|}{ Total }} & \multirow{3}{*}{ P Value } \\
\hline & \multicolumn{2}{|c|}{ Depression } & \multicolumn{2}{|c|}{$\begin{array}{c}\text { Not } \\
\text { Depression }\end{array}$} & & & \\
\hline & $\mathbf{F}$ & $\%$ & $\mathbf{F}$ & $\%$ & $\mathbf{N}$ & $\%$ & \\
\hline Elementary school & 9 & 22 & 32 & 78 & 41 & 100 & \\
\hline Junior high school & 1 & 9,1 & 10 & 90,9 & 11 & 100 & \\
\hline Senior high school & 1 & 16,7 & 5 & 83,3 & 6 & 100 & 0,025 \\
\hline College & - & - & 1 & 100 & 1 & 100 & \\
\hline Amount & 11 & 18,6 & 48 & 81,4 & 59 & 100 & \\
\hline
\end{tabular}

Based on the table above it can be known that the percentage who experienced a higher incidence of depression was found in elementary school-educated respondents with sltp-educated respondents of $22 \%: 9.1$ $\%$.
Ha's decision was accepted which meant there was a meaningful link between education and the incidence of depression in the elderly.

Chi Square's analysis yielded $\mathrm{p}=0.025<\alpha 0.05$. 
Table 11. Relationship of Marital Status with The Incidence of Depression in Korong Lohong Working Area of Public Health Center Sei sarik Padang Pariaman Regency

\begin{tabular}{|c|c|c|c|c|c|c|c|}
\hline \multirow{2}{*}{ Marital status } & \multicolumn{4}{|c|}{ Incidence of depression } & \multicolumn{2}{|c|}{ Total } & \multirow{3}{*}{ P Value } \\
\cline { 2 - 7 } & \multicolumn{2}{|c|}{ Depression } & \multicolumn{2}{|c|}{$\begin{array}{c}\text { Not } \\
\text { Depression }\end{array}$} & \multicolumn{2}{|c|}{} & \\
\cline { 2 - 7 } & $\mathbf{F}$ & $\mathbf{\%}$ & $\mathbf{F}$ & $\mathbf{\%}$ & $\mathbf{N}$ & $\mathbf{\%}$ & \\
\hline Married & 7 & 53,8 & 6 & 46,2 & 13 & 100 & \multirow{2}{*}{0.001} \\
\hline Not married & 4 & 8,7 & 42 & 91,3 & 46 & 100 & \\
\hline Amount & $\mathbf{1 1}$ & $\mathbf{1 8 , 6}$ & $\mathbf{2 2}$ & $\mathbf{8 1 , 4}$ & $\mathbf{5 9}$ & $\mathbf{1 0 0}$ & \\
\hline
\end{tabular}

Based on the table above it can be known that the percentage who experienced a higher incidence of depression was found in respondents who did not mate with respondents who married which was $53.8 \%: 8,7$ $\%$.

Chi Square's analysis yielded $p=0.001<\alpha 0.05$. Ha's decision was accepted which meant there was a meaningful relationship between marital status and the incidence of depression in the elderly.

\section{Discussion}

\section{Univariat analysis}

Age

The analysis of the age of respondents found more than half of respondents were 37 people $(62.7 \%)$ aged 60 - 65 years. Characteristics of a person's age can a. reflect appearance, social status, education, socioeconomic status, risk of injury or health problems in a population group. Age is also a specific determinant of risk and determinants of exposure in a particular field of work and is a predictor of the health status and condition in which a population works (Widyastuti, 2005).

\section{Gender}

Analysis of the respondent's gender found more than half of respondents were $36(61 \%)$ have a male gender. Although diagnostic criteria are the same for all genders, women are more susceptible to depression. Women are more at risk of depression due to hormonal changes as well as differences in characteristics between the two, said the head of the Psychiatric Division of the Department of Psychiatry fkui dr. Danardi Sosrosumihardjo, SpKJ (K).

This was revealed by a psychiatrist from the University of Nebraska College of Medicine Subhash C Bathia MD. She revealed that depression is the same for all genders. However, women are more likely to feel feelings of guilt, anxiety, increased or even decreased appetite, sleep disturbances, and eating disorders. He added that women are more likely to experience depression once and a half times more than men. He reiterated that not all women experience this.

In the results of the study there are differences from the above theories. According to the researcher's analysis, that in general elderly women can live independently in daily activities, women are more able to adapt to their conditions and circumstances. While men can not forget their heyday in youth. He was always served and respected. This may have something to do with minangkabau culture.

The results of this study are also the same as the research conducted by Nia Fitria (2009). In his research on factors related to the incidence of depression in the elderly in Public Health Center Kampung Dalam, it was also found that more than half of respondents were male.

Employment

Analysis of respondents' work found more than half of respondents were $34(57.6 \%)$ Work. The characteristics of a person's work can reflect income, social status, education, socioeconomic status, risk of injury or health problems in a population group. Employment is also a specific determinant of risk and exposure determinants in a particular field of work and is a predictor of the health status and condition in which a population works (Widyastuti, 2005).

In general, these changes begin in retirement. Although the ideal purpose of retirement is for the elderly to enjoy the old days or the old days guarantee, in reality it is often interpreted as the opposite because retirement is often interpreted as loss of income, position, position, role, activities, status and self-esteem.

The results of this study are also the same as the research conducted by Nia Fitria (2009). In his research on factors related to the incidence of depression in the elderly in Public Health Center Kampung Dalam, it was also found that more than half of respondents worked.

The results showed that more than half of respondents who worked but still many respondents who did not work that caused them to be at risk of depression in old age, according to the theory that someone who previously worked but in old age did not 
work became a burden of mind that can interfere with health because they feel lost in terms of income, position or self-esteem.

\section{Education}

Analysis of respondents' work found that more than half of respondents were $41(69.5 \%)$ elementary school equivalent education.

The characteristics of a person's education can reflect income, social status, education, socioeconomic status, risk of injury or health problems in a population group. Employment is also a specific determinant of risk and exposure determinants in a particular field of work and is a predictor of the health status and condition in which a population works (Widyastuti, 2005).

\section{Marital status}

The analysis of the respondent's marital status was found by more than half of respondents, namely 46 pairs $(78 \%)$ of respondents.

In the life of the elderly there are those who do not perform marriages or prefer to live single for the rest of their life. With the presence of marriage can also provide psychic support to the tide, but there are also cases that even a life partner who makes a problem, thus making there is pressure both physically and psychically towards the married couple.

The results of this study are also the same as a. the research conducted by Nia Fitria (2009). In his b research on factors related to the incidence of depression in the elderly in Public Health Center Kampung Dalam, it was also found that more than half of respondents were still married.

\section{Incidence of depression}

More than half of respondents were not depressed, with 48 people $(81.4 \%)$ depressed. Depression is a mood disorder. Mood is a pervasive and sedentary mood of feeling experienced internally and that affects a person's behavior and his perception of the world (Sadock and Sadock, 2007).

Depression is a depressed mood that can be a diagnosis of a disease or as a symptom or response to other disease conditions and environmental stress. Depression in the elderly is depression according to the criteria of DSM-IV. Major depression in the elderly is diagnosed when the elderly show one or two of the two core symptoms (depressed mood and loss of interest in a thing or pleasure)along with four or more of the following symptoms for a minimum of 2 weeks: useless self-feelings or feelings of guilt, reduced ability to concentrate or make decisions, fatigue, agitation or psychomotor retardation, insomnia or hypersomnia, significant changes in weight or appetite, and repeated thoughts about death or the idea of suicide (American Psychiatric Association/ APA, 2000).

\section{Bivariate analysis}

Bivariate analysis is performed to see if there is a relationship between variables:

The Respondent's Age Relationship with The Incidence of Depression

Based on the table above it can be found that the percentage who experienced a higher incidence of depression was found in respondents aged more than 76 $\%$ which is $57.1 \%$

Chi Square's analysis yielded $\mathrm{p}=0.045<\alpha 0.05$. Ha's decision was accepted which meant there was a meaningful link between the sexes and the incidence of depression in the elderly. According to dr. Fatimah Haniman SpKJ, mental expert of RSU Dr. Soetomo Surabaya, women are more susceptible to depression than men. But in fact more women are more resistant to depression so it doesn't come down to suicide. It should be noted, suicides are more committed by men. Women are more likely to have the opportunity to vent their stress as a trigger for depression than men. Most neighborhoods tolerate and consider it fairness if a woman cries, or screams to shed her anger and sadness. While in men, they feel a sign of their weakness.

Respondent's Gender Relationship with incidence of depression

Based on the table above it can be known that the percentage who experienced a higher incidence of depression was found in respondents who were female with male respondents being $21.7 \%: 16.7 \%$.

Chi Square's analysis yielded $p=0.037<\alpha$ 0.05. Ha's decision was accepted which meant there was a meaningful link between the sexes and the incidence of depression in the elderly.

According to dr. Fatimah Haniman SpKJ, mental expert of RSU Dr. Soetomo Surabaya, women are more susceptible to depression than men. But in fact more women are more resistant to depression so it doesn't come down to suicide. It should be noted, suicides are more committed by men. Women are more likely to have the opportunity to vent their stress as a trigger for depression than men. Most neighborhoods tolerate and consider it fairness if a woman cries, or screams to shed her anger and sadness. While in men, they feel a sign of their weakness.

The results of this study are also the same as the research conducted by Nia Fitria (2009). In his research on factors related to the incidence of depression in the elderly in Public Health Center Kampung Dalam, also found one of the factors that 
causes depression in the elderly is gender. Respondent's Employment Relationship with incidence of depression

Based on the table above it can be known that the percentage of experiencing a higher incidence of depression was found in respondents who did not work with working respondents which was $29.4 \%: 21,4.0 \%$.

Chi Square's analysis found basil $p=0.017<\alpha$ 0.05 . Ha's decision was accepted which meant there was a meaningful link between work and the incidence of depression in the elderly.

Work is indeed one of the needs of human life. Because by working one can meet the needs of his life. Kartono (2003) suggested that the work, in addition to providing materil in the form of salaries, wealth and various material facilities, also provides a nonmaterial social reward namely social status and social process. So a great sense of pride and interest in work with all ranks, positions, honors and symbols of greatness becomes a powerful incentive for a person to love the job. The results of this study are also the same as the research conducted by Nia Fitria (2009). In his research on factors related to the incidence of depression in the elderly in Public Health Center Kampung Dalam, where there is a meaningful relationship between work and the incidence of mental disorders (depression) in the elderly.

The Respondent's Educational Relationship with The Incidence of Depression

Based on the table above it can be known that the percentage of experiencing a higher incidence of depression was found in respondents who were educated equal to elementary school with respondents namely 22 $\%: 9,1 \%$

Chi Square's analysis found basil $p=0.025<\alpha$ 0.05 . Ha's decision was accepted which meant there was a meaningful link between work and the incidence of depression in the elderly.

The Relationship of The Respondent's Marital Status with the Incidence of Depression

Based on the table above it can be known that the percentage of experiencing a higher incidence of depression found in respondents who did not marry with married respondents was $53.8 \%:, 8.7 \%$.

Chi Square's analysis yielded $\mathrm{p}=0.001<\alpha$ 0.05 . Ha's decision was accepted which meant there was a meaningful relationship between marital status and the incidence of depression in the elderly.

In the life of the elderly there are those who do not perform marriages or prefer to live their whole life. With the presence of marriage can also provide psychic support to the partner, but there are also cases that even a living partner makes a problem, thus making there is pressure both physically and psychically towards the married couple. In old age often experience loneliness due to the loss of a partner. There is no doubt that marriage is common place to overcome the problem of loneliness. Lonely elderly can fall into a state of depression.

A common problem that often occurs in the elderly who have lost a life partner is the problem of loneliness. Loneliness in the elderly can cause the elderly to secede from the environment. But basically the loneliness of losing this life partner can be overcome by the support of other families such as children (Bruno, F.J, 2000)

The results of this study are also the same as the research conducted by Nia Fitria (2009). In his research on factors related to the incidence of depression in the elderly in Public Health Center Kampung Dalam, where there is a meaningful relationship between marital status and the incidence of mental disorders (depression) in the elderly.

Researchers with elderly women at Sei Sarik Health Center said they did not feel lonely after being left behind by their husbands because there are now grandchildren in care. But the elderly man said that feeling lonely after his wife passed away, so they remarried

\section{CONCLUSION AND SUGGESTION Conclusion}

More than half of respondents $(62.7 \%)$ has a lifespan of 60-65 years. More than half of respondents $(61.0 \%)$ male. More than half of respondents $(57.6 \%)$ Working. More than half of respondents $(69.5 \%)$ in elementary school. More than half of respondents (78.0\%) still married. More than half of respondents $(81.4 \%)$ there is family support. More than half of respondents $(81.4 \%)$ depression in the elderly.

There is a meaningful relationship of age with the incidence of depression in the elderly in the Sei Sarik Public Health Center Area, with (p value 0.014). There is a meaningful relationship between the sexes and the incidence of depression in the elderly in the Sei Sarik Public Health Center Area, with (p value 0.014). There is a meaningful link between work and the incidence of depression in the elderly in the Sei Sarik Public Health Center Area, with ( $p$ value 0.045). There is a meaningful link between education and the incidence of depression in the elderly in the Sei Sarik Public Health Center Area, with (p value 0.032).

There is a meaningful relationship between marital status and the incidence of depression in the elderly in the Sei Sarik Public Health Center Area, with ( $\mathrm{p}$ value 0.020 ). There is a meaningful link between family support and the incidence of depression in the 
elderly in The Sei Sarik Public Health Center Area, with (p value 0.032 )

\section{Sugesstion}

It is expected that respondents can receive good old age by filling the busyness by engaging in household affairs, cleaning houses, mosque groups and activities utilizing the yard to avoid boredom that can lead to depression. It is expected for the family to always provide support to the elderly in order to provide activities to avoid boredom such as light work and paying attention while doing the work. We hoped that The Health Center of Sei Sarik will be able to improve the elderly posyandu service by participating in the role of elderly families.

\section{REFERENCES}

[1] Afida N. (2000). Hubungan Pemenuhan Kebutuhan Interaksi Sosial dengan Tingkat Depresi pada Lansia di Panti Werdha Anima, Indonesiaan Psychological Journal

[2] Agus, D. (2002). Gangguan Depresi pada Lansia Usia, Majalah Kedokteran Atma Jaya

[3] Ahmadi, A. (2002). Psikologi Social. Jakarta : Rineka Cipta

[4] Amir, N. (2005). Depresi : Aspek Neurologis Diagnosis dan Tatalaksana. Jakarta : Balai Penerbit FKUI

[5] Arikunto, S. (2002). Prosedur Penelitian Suatu Pendekatan Praktik. Jakarta : Rineka Cipta

[6] Arikunto, S. (2006). Prosedur Penelitian Suatu Pendekatan Praktek, Edisi Kesembilan, Rineka Cipta, Jakarta.

[7] Asmika. (2008). Prevalensi Depresi dan Gambaran Stressor Psikososial. Jurnal Kedokteran Brawijaya.

[8] Chandra, R. (2003). Konflik: Dalam Kehidupan Sehari-hari, Yogyakarta : Penerbit Kanisius

[9] DepKes RI. (2011). Keputusan Menteri Kesehatan RI No.983/MenKes/ SK/XI/1992. Pedoman Organisasi Rumah Sakit Umum.

[10]Departemen Kesehatan R.I. 2003. Visi Misi Indonesia Sehat 2010, Jakarta

[11] Gunarsa, S.D. (2004). Dari Anak Sampai Usia Lanjut : Bunga Rampai Psikologi Anak, Bpk Gunung Mulia

[12] Hawari. D. (2006). Manajemen Stress Cemas dan Depresi. Jakarta: Balai Penerbit FKUI

[13] Irma Tania, (2014), Faktor-Faktor Yang Berhubungan Dengan Kejadian Depresi Pada Lansia di Wilayah Kerja Public Health Center Sintuk Kabupaten Padang Pariaman (KTI)

[14] Kaplan, H.I, Sadock, B.J. (2008). Ilmu Kedokteran Jiwa Darurat. Jakarta: Widya Medika
[15] Nia Fitri, 2009. KTI. Faktor-Faktor Yang Berhubungan Dengan Kejadian Depresi Pada Lansia di Public Health Center Kampung Dalam.

[16] Notoatmodjo, Soekidjo. (2010). Metodologi Peneliatian Kesehatan. Jakarta: PT. Rineka Cipta

[17]Riduan. (2007). Skala Pengukuran VariabelVariabel Penelitian, Bandung: Alfa Beta.

[18] Shives, L.R. (2008). Basic Concept of Psychiatric Mental Health Nursing. New York Lippincot

[19] Victor, C. (2004). Lonelines, Social Isolation and Living Alone in Later Life. Diakses pada tanggal 17 Februari 2014 